\author{
Marzenna Nowicka \\ Uniwersytet Warmińsko-Mazurski w Olsztynie \\ marzenna.nowicka@uwm.edu.pl
}

\title{
Portal Scholaris jako platforma cyfrowej edukacji wczesnoszkolnej - zmiana czy cementowanie utartych ścieżek dydaktycznych?
}

\section{Summary \\ The Scholaris portal as a platform of digital early childhood education - the change or strengthening of usual didactic paths?}

Scholaris is a portal of MEN agenda with educational electronic resources designated for teachers of all stages of education. The aim of the research was to identify the promoted model of digital early childhood education. An analysis of the content of portal showed a focus on technology being used to illustrate the content covered by the teaching program, limitation of openness to other communities and places on the internet, negligence of the communication between education entities and the hegemony of digital content for the teacher to reproduce. The digitality on the portal is seen as a visualsound enhancement of classes and the technical facilitation of the teacher's work. In spite of the current innovative trends, the general model promoted on the website is seen as functional-behavioral.

Słowa kluczowe: środowisko uczenia się, dyskursy edukacji, cyfryzacja szkoły, Scholaris

Keywords: learning environment, education discourses, school digitalization, Scholaris

Poszukiwanie rezerwuarów ożywczych inspiracji dla edukacji wczesnoszkolnej odbywa się wieloma drogami. Jedną z nich jest otwarcie się na media i kulturę cyfrową. Era nowych nowych mediów (Levinson 2010) zmusza instytucję szkoły do działań w dwóch kierunkach, pierwszym - stosunkowo prostym, choć wymagającym nakładów finansowych, obejmującym wprowadzanie cyfrowego oprzyrządowania szkół, i w drugim - zdecydowanie trudniejszym, bo dotyczącym przemiany modelu dydaktycznego w celu efektywnego i adekwatnego wykorzystywania mediów w edukacji dzieci. Oba te działania związane są z diametralną zmianą kontekstu procesu uczenia się przebiegającego w szkole. W refleksji pedagogicznej dotyczącej tej kwestii funkcjonują dwa określenia - przestrzeni i środowiska edukacyjnego. Są one często zamiennie używane (Wieczorek-Tomaszewska 2013: 29), choć wywodzą się z różnych podejść do opisywania rzeczywistości, w której zanurzony jest człowiek. Przestrzeń, spleciona z doświadczaniem miejsca i czasu, wyznacza ramy przebiegających zjawisk (Mendel 2006; Zwiernik 2015) i jawi się jako określenie szersze w stosunku do środowiska edukacyjnego, wyznaczonego przez konkretne elementy fizyczne, społeczne, wirtualne, składające się łącznie na strukturę tej przestrzeni (Nowak 2014). Współczesne rozumienie środowiska uczącego jest szerokie i obejmuje 
„bezpośredni kontekst każdego zdarzenia związanego z uczeniem się” (Dumont, Istance 2013: 53). W odniesieniu do szkoły wyznaczanie komponentów sytuacji uczenia się, którymi są: uczeń, nauczyciel (edukator), treści oraz fizyczne i technologiczne warunki, samo w sobie nie określa środowiska, buduje je dopiero dynamika interakcji i jakość wzajemnego oddziaływania tych elementów (tamże: 52). Mariola Chomczyńska-Rubacha definiuje środowisko jako „zespół zewnętrznych wobec jednostki bodźców”, które w warunkach szkoły stanowią „kontekst nadający jakość szkolnej codzienności i warunkujący efekty uczenia się" (2003, s. 240). Oddziaływanie tych bodźców, jak zauważa Jolanta Kruk, i aktywizowanie przez nie ucznia w środowisku edukacyjnym nie zawsze ma jednakową moc prorozwojową. Za zdecydowanie niewystarczające uznaje się dziś podejście tradycyjne, w którym uwaga skoncentrowana jest na dostarczaniu „odpowiednio zróżnicowanego zestawu pomocy i środków dobranych pod kątem ich ilustratywnej roli w kształtowaniu pojęć i zasobów wiedzy” (Kruk 2009: 490). Współcześnie mówi się o interakcyjnym modelu środowiska uczenia się, w którym: ,to już nie nauczyciel naucza z użyciem środków poglądowych, tylko środowisko klasy szkolnej (i nie tylko jej) jest bezpośrednim źródłem ważnych impulsów edukacyjnych i konfliktu poznawczego" (tamże: 494). Podejście to jest zgodne z ustaleniami Piageta i innych konstruktywistów, według których operowanie tylko kodem symbolicznym i obrazowym nie stanowi wystarczającej drogi do nabywania pojęć. Dzieci konstruują swoją wiedzę na drodze aktywnej eksploracji otoczenia prowadzonej poprzez czynności fizyczne bądź umysłowe (Wadsworth 1998: 172). Restrukturyzacja wiedzy następuje w sytuacji konfliktu poznawczego związanego z brakiem równowagi poznawczej. Zatem tylko środowisko, w którym uczniowie mają okazję konfrontowania doświadczeń i wyników sprzecznych z ich przewidywaniami dostarcza tworzywa dla rozwoju dyspozycji intelektualnych. To środowisko, które „samo prowokuje poznawczo i zawiera w sobie potencjał zdolny doprowadzić podmiot do zachowań sprzyjających jego rozwojowi” (Kruk 2009: 494). Interaktywność jest podstawową cechą takiego środowiska i, w rozumieniu J. Kruk, oznacza obecność elementów umożliwiających podejmowanie przez ucznia samodzielnej aktywności badawczej, eksplorację poprzez czynności manipulacyjne, intelektualne badania drogą samodzielnego testowanie hipotez czy intuicyjnego odkrywania praw, a także odbywanie ćwiczeń w posługiwaniu się narzędziami (tamże: 498). Zatem to otoczenie bogate w bodźce, wyposażające ucznia w techniki pracy umysłowej właściwe roli odkrywcy i badacza. Model środowiska interakcyjnego bezpośrednio przystaje do wyróżnionego przez Dorotę Klus-Stańską dyskursu konstruktywistyczno-rozwojowego, obecnego w podejściach do edukacji najmłodszych. W dyskursie tym uczenie się to nie nabywanie wiedzy, ale „aktywna, eksploracyjna, samodzielna pod względem koncepcyjnym i decyzyjnym konstrukcja i rekonstrukcja umysłowych modeli rzeczywistości" (Klus-Stańska 2009: 61). W związku z tym działania nauczyciela na lekcji zogniskowane są na uruchamianie prowokacji poznawczych i organizację warsztatu umożliwiającego przeprowadzanie samodzielnych eksploracji. W podejściu tym dużą rolę przywiązuje się do wiedzy osobistej ucznia budowanej na drodze zaangażowania w rozwiązywanie problemów oraz do błędu jako ważnego elementu pro- 
cesu badawczego (tamże: 64). Jak podkreśla D. Klus-Stańska, dyskurs inspirowany konstruktywizmem jest wyspowo obecny w polskiej szkole (tamże: 63), a edukacja dzieci wpisuje się głównie w dyskurs opozycyjny w stosunku do wyróżnionego, określny jako funkcjonalno-behawiorystyczny. Dyskurs ten ma wyraźnie opresyjny charakter, co wynika z podstawowych założeń, że zmiany w uczniu dadzą się wywołać i utrwalić przez odpowiednie bodźce, a uczenie się polega na przyswajaniu informacji i instrukcji pochodzących z zewnętrznego przekazu. W perspektywie tego dyskursu nie ufa się kompetencjom dzieci, a oddziaływanie nauczyciela ma charakter instrumentalny, wdrożeniowo-interwencyjny, skoncentrowany na sprawności odtwarzania wiadomości i umiejętności przez uczniów (tamże: 49-52).

Warto rozważyć, w jaki model organizacji środowiska uczącego się i związany z tym dyskurs edukacji wczesnoszkolnej wpisują się inicjatywy cyfryzacji szkoły. W niniejszym artykule przedstawiam wyniki badań dotyczących portalu Scholaris, wytworzonego intencjonalnie w celu rozszerzenia środowiska cyfrowego dydaktyki szkolnej.

Scholaris jest to portal z edukacyjnymi zasobami elektronicznymi przeznaczony dla nauczycieli wszystkich etapów kształcenia, począwszy od przedszkola na szkole ponadgimnazjalnej skończywszy. Powstał jako część rządowego programu rozwijania kompetencji uczniów i nauczycieli w zakresie stosowania technologii informacyjno-komunikacyjnych Cyfrowa szkoła. Za realizację projektu odpowiedzialna jest agenda MEN - Ośrodek Rozwoju Edukacji ${ }^{1}$. Nowa wersja portalu edukacyjnego Scholaris (2013) powstała w oparciu o portal istniejący od roku 2004 (http://bms.com.pl/case-study-system-scholarisdla-osrodka-rozwoju-edukacji/, dostęp: 07.02.2017). Zmiany w MEN nie ograniczyły funkcjonowania portalu, kolejne ekipy ministerialna kontynuują politykę cyfryzacji szkół i portal jest udoskonalany technicznie, aktualizowany merytorycznie ${ }^{2}$ i stale uzupełniany o nowe materiały dydaktyczne. Jak podkreślają z dumą twórcy portalu, umieszczono na nim zasoby edukacyjne odpowiadające 75 proc. treści obowiązującej podstawy programowej kształcenia ogólnego, zaś głównym celem ich działań jest: „wsparcie nauczycieli w przygotowaniu ciekawych, często interaktywnych zajęć poprzez dostarczenie im gotowych i sprawdzonych materiałów edukacyjnych" (http://scholaris.pl/onnas).

\section{O badaniu}

Głównym celem prezentowanych tu badań była identyfikacja promowanego przez MEN modelu cyfrowej edukacji wczesnoszkolnej ${ }^{3}$. Problem główny zawierał się w pytaniu: Jak na portalu Scholaris rozumiane jest wykorzystywanie technologii cyfrowych $w$ edukacji dzieci? Jego uszczegółowienie stanowiły dwa pytania, pierwsze dotyczące do warszta-

\footnotetext{
1 Projekt realizowany przez ORE w ramach Programu Operacyjnego Kapitał Ludzki, Priorytet III, Działanie 3.3, Poddziałanie 3.3.3, współfinansowane z Europejskiego Funduszu Społecznego.

2 Dostosowanie do Podstawy programowej z 14 lutego 2017 roku, aktualny wykaz podręczników.

3 „Cyfrowość edukacji” rozumiana jest tu jako promowanie, rozpowszechnianie i wykorzystanie szeroko rozumianej techniki cyfrowej w działaniach związanych z edukacją dzieci w szkole.
} 
tu pracy nauczyciela edukacji wczesnoszkolnej: Jak rozumiane jest na portalu Scholaris wykorzystywanie narzędzi cyfrowych $w$ budowaniu warsztatu metodycznego nauczyciela wczesnej edukacji? oraz drugie, odnoszące się do wykorzystywania cyfrowych zasobów w praktyce edukacyjnej: Jaka jest orientacja dydaktyczna proponowanych na portalu Scholaris zasobów edukacyjnych?

Zastosowaną metodą badawczą była etnografia wirtualna, w której skupiłam się na analizie tekstów zamieszczonych na portalu internetowym (Cichocki, Jędrkiewicz, Zydel 2012: 206). W toku badania przekazów cyfrowych czyniłam starania by „naszkicować obraz założeń i znaczeń, składających się na kulturowy świat, którego częścią są analizowane teksty" (Peräkyä 2009: 326). Ze względu na ogromną liczbę danych zawartych na portalu, przy budowaniu korpusu danych zastosowałam metodę stopniowego uszczegółowiania i redukcji (top down approach). Punktem wyjścia w tej metodzie jest „uniwersum możliwych tekstów", które zostaje zawężane stopniowo w procesie selekcji, co daje w efekcie możliwy do ogarnięcia przez badacza ,wyspecjalizowany tematyczny korpus diachroniczny" (Mautner 2011: 60-61). Zatem po wejściu na stronę portalu Scholaris, do poszukiwania odpowiedzi pierwszy problem szczegółowy wybierałam opcję: edukacja wczesnoszkolna, następnie: wszystkie zasoby. I tu analizowałam wszystkie okna dotyczące tego poziomu. Do rozwiązania drugiego problemu szczegółowego w analizie strony posuwałam się dalej, wybierałam zasoby: najczęściej reprezentowane, którymi okazały się scenariusze (w liczbie 841), więc wybierałam opcję: scenariusze, w tym: najnowsze (po ostatniej reformie programowej z 2017r.). Przy wyświetlaniu stron ze scenariuszami wybierałam opcję: 48 na stronę, a po wejściu na dany scenariusz korzystałam też ze stron z materiałami dodatkowymi, na które wskazywał pakiet (jeśli był).

\section{Cyfrowość warsztatu nauczyciela na portalu Scholaris}

W wyniku ogólnego oglądu strony głównej portalu Scholaris poświęconej edukacji wczesnoszkolnej i możliwości działania jakie otwiera ona przed odbiorcami można powiedzieć, że rozumienie wykorzystywania technologii w budowaniu warsztatu pracy nauczyciela charakteryzuje się określonymi cechami. Można je opisać w następujący sposób:

1) cyfrowość poglądowa - koncentracja na wykorzystywaniu technologii do upoglądawiania treści objętych programem nauczania w poszczególnych klasach;

2) cyfrowość zamknięta - ograniczenie otwartości na inne społeczności i miejsca w sieci na inne miejsca w sieci i społeczności i inicjatywy w sieci oraz ograniczony zakres odbiorców;

3) cyfrowość niekomunikacyjna - zaniedbanie możliwości komunikowania się pomiędzy podmiotami edukacji;

4) cyfrowość bierna - hegemonia zasobów cyfrowych do odtworzenia i ograniczona cyfrowa aktywność nauczyciela. 


\section{Cyfrowość poglądowa}

Portal Scholaris oferuje nauczycielom bardzo rozległe repozytorium materiałów edukacyjnych liczące 3626 zasobów. Sugerując się danymi liczbowymi przedstawionymi na stronie, a dotyczącymi poszczególnych typów zasobów można powiedzieć, że wykorzystanie technologii cyfrowych w szkole rozumiane jest głównie jako upoglądawiania treści zawartych w podstawie programowej. Filmy i animacje, nagrania dźwiękowe, zdjęcia i ilustracje, prezentacje mulitmedialne stanowią blisko trzecią cześć oferowanych materiałów. Nauczyciel ma okazję wykorzystać na zajęciach doskonałej jakości reprezentacje wizualne świata, w który wprowadza dziecko. Na fotografiach i w filmach przedstawiane są obiekty przyrody ożywionej i nieożywionej, zjawiska fizyczne i chemiczne, różne wytwory działalności człowieka. Jak można przypuszczać, kolorowe, dynamiczne obrazy wsparte dźwiękiem znacznie lepiej zainteresują dzieci niż statyczne ilustracje czy modele dostępne w podręcznikach szkolnych. Jednakże widoczna jest tu koncentracja na ilustratywnej roli środowiska dydaktycznego. Twórcy portalu przez liczbę zamieszczonych materiałów wzmacniają rozpowszechniony w transmisyjnej szkole kult odzwierciedlania prezentowanych treści (Kruk 2009: 490).

\section{Cyfrowość zamknięta}

Portal Scholaris to typowe branżowe miejsce, przeznaczone wyłącznie dla nauczycieli. Zadziwia fakt, że pominięto w nim dwie inne społeczności bezpośrednio związane z edukacją szkolną, to jest dzieci i ich rodziców. Na portalu nie przewiduje się odrębnej strefy dla ucznia i nie ma na nim strefy dla rodzica.

Również zakres tego, co oferowane jest nauczycielom przejawia zamknięty charakter. Portal Scholaris okazuje się być portalem dość hermetycznym, na którym proponuje się duże zasoby materiałów edukacyjnych, ale wyłącznie własnych, zgromadzonych przez Ośrodek Rozwoju Edukacji i pozyskanych od jednostek z tym ośrodkiem współpracujących. Wskazuje to z jednej strony na zamiar dbałości ORE o jakość prezentowanych treści, jednakże zdecydowanie ogranicza możliwości kreowania zajęć z wykorzystaniem innych, ciekawych i aktywizujących zasobów. Scholaris jest zamknięty na różne miejsca w sieci, w których rejestr pomocy jest niezwykle bogaty i na bieżąco uzupełniany. Przykładowo, brak linków zewnętrznych do takich popularnych i darmowych miejsc w sieci, jak: edukator.pl, Klik TiK, Edunews.pl., mInstructor, mCourser, LearningApps.org, albo też komercyjnych częściowo lub całkowicie, jak Edustore.eu, Squla, DrOmnibus, EduSense, Think! itp. Brak linków do miejsc, z których za darmo i legalnie można pobierać aplikacje, interaktywne moduły, zdjęcia i muzykę. W związku z zamkniętą koncepcją portalu, a być może także z pewną ociężałością w zakresie bieżącego uzupełniania zasobów (ostanie uzupełnienie działu edukacji wczesnoszkolnej nastąpiło w styczniu 2018), w Scholarisie brak e-nowości i informacji na ich temat. Odbiorcy nie dowiedzą się niczego nowego na przykład o grywalizacji, interaktywnej podłodze, czy nowych aplikacjach do uczenia programowania w szkole. 


\section{Cyfrowość niekomunikacyjna}

Jak już wyżej zaznaczyłam portal Scholaris nie jest otwarty na wiele ważnych miejsc w sieci, nie stwarza się zatem możliwości aktywnego bycia w tej sieci i komunikowania się z jej wykorzystaniem. Jako portal dla nauczycieli nie proponuje rozszerzonego dostępu do innych platform, na których ci nauczyciele kontaktują, organizują różne inicjatywy i działają wspólnie. Nie umieszczono na nim linków do bogów, webinariów, nie wskazano żadnych funpages. Szkoda, że użytkownicy strony nie są informowani o działaniach społeczności nauczycieli skupionych na stronach ,eduzmieniaczy” - Supebelfrów RP i ich podstronach. Nie są świadomi ogłaszania nowych konkursów (poza tymi organizowanymi przez ORE), czy innych inicjatyw, w których z uczniami mogliby brać udział. Nie ma informacji o szkoleniach, nowych publikacjach czy akcjach, nie ma komentarzy bieżących wydarzeń w zakresie edukacji. Scholaris został zintegrowany wyłącznie z najpopularniejszymi portalami ogólnospołecznościowymi - Facebook, Twitter i Google+.

Cyfrowa niekomunikacyjność portalu przejawia się też $\mathrm{w}$ zupełnym zignorowaniu kontaktowania się ze społecznością uczniów (z wyjątkiem ich testowania) oraz rodziców. Ogromnym mankamentem jest brak e-dziennika, który umożliwiałby wielopłaszczyznową komunikację z uczniami i ich rodzicami. Korzystanie z portalu Scholaris nie umożliwia też integrowania samej społeczności uczniowskiej. Nie ma możliwości budowania wspólnoty klasowej poprzez narzędzia cyfrowe, jak na przykład z wykorzystaniem aplikacji ClassDojo.

\section{Cyfrowość bierna}

Rozumienie cyfrowości warsztatu nauczyciela na platformie Scholaris można uznać za wspierające odtwórczość nauczyciela. W Scholarisie dominują bowiem zasoby gotowe do pobrania i duplikowania na zajęciach w szkole. Zatem prawie wszystko jest już opracowane, podane i koncepcyjnie skończone. Co z pomocą Scholarisa nauczyciel może tworzyć? - tylko prezentacje multimedialne i testy dla uczniów. Twórcy portalu nie zakładają wykorzystywania przez nauczycieli nowoczesnych narzędzi do generowania pomocy dydaktycznych i usprawniających organizację procesu dydaktycznego. Nie ma możliwości samodzielnego tworzenia i przeprowadzania interaktywnych quizów, nie można tworzyć interaktywnych gier czy generować i wykorzystywać kodów QR. Brakuje też wszelkiego typu generatorów kart pracy, czy innych pomocy często wykorzystywanych w nauczaniu początkowym. Twórcy portalu zakładają bardzo wąską przestrzeń kreacji cyfrowej i w dodatku przewidują w niej miejsce tylko dla nauczyciela.

\section{Orientacja dydaktyczna proponowanych zasobów}

Poszukiwanie odpowiedzi na drugi problem badawczy obejmowało analizę zasobów zgromadzonych w sieci, w których zgodnie z przyjętą procedurą budowania korpusu danych uwzględniono najnowsze scenariusze (zamieszczone po 2017 roku, czyli po wpro- 
wadzenia ostatniej reformy) i zintegrowane z nimi pomoce dydaktyczne w postaci kart pracy oraz e-doświadczeń.

Biorąc pod uwagę wielość głosów krytycznych skierowanych pod adresem współczesnej polskiej szkoły, z satysfakcją trzeba odnotować wyraźny trend ujawniający się w scenariuszach proponowanych na stronach Scholarisa w kierunku kreowania edukacji konstruktywistycznej na etapie nauczania początkowego. Wyraża się to akcentowaniem w niektórych konspektach wielokierunkowego i wielozmysłowego poznania przez dziecko otaczającego świata i dbałością o uruchamianie sfery emocjonalnej ucznia i motywowania go do różnego typu aktywności. Proponowana tematyka zajęć służy zaspokajaniu potrzeb intelektualnych dzieci, wyznaczane są nowe, nieschematyczne obszary działań, jak na przykład: Co wiemy o reklamie? Skąd się biora dźwięki?, Jak zrobić domowe karmelki? Największe novum w tym zakresie stanowią propozycje tzw. e-doświadczeń, które oprócz zainteresowania uczniów podejmowaną problematyką, w swym zamiarze są okazją do gromadzenia wiedzy w sposób preferowany w dydaktyce konstruktywistycznej, zatem przez osobiście przeprowadzane eksperymenty i doświadczenia. Zgodnie z zaleceniami konstruktywistów proponuje się też wiele pracy w grupach czy zespołach, akcentuje się również właściwości indywidualne ucznia, proponując działania na różnych poziomach.

Jednakże, co należy mocno podkreślić, propozycje ukierunkowane na aktywność badawczą dziecka zawierają wiele usterek. Niektóre są na tyle obciążające, że idea konstruktywizmu zostaje w nich zupełnie zaprzepaszczona. I to zagubienie głównych wskazań dydaktyki inspirowanej konstruktywizmem decyduje, że proponowana na portalu edukacja ma jednak wyraźny charakter funkcjonalno-behawioralny. Chodzi tu głównie o zbytnie upraszczanie i wypaczanie metody projektowania okazji edukacyjnych Ryszarda Łukaszewicza (Łukaszewicz 2010) oraz idei projektu „Włącz myślenie” opartym na programie nauczania opracowanym przez zespół Małgorzaty Skury (Skura i in. 2014), do których nawiązują twórcy scenariuszy. Ze względu na to, że nie ma żadnych linków odsyłających do tego programu ani powiązanego z nim poradnika (Zasada 2014), w konsekwencji nie sugeruje się poszerzania refleksji nad danymi materiałami, a wręcz promuje bezmyślne z nich korzystanie. Tymczasem wiele konspektów trywializuje wskazania konstruktywizmu, obecne są w nich usterki trudne do bezpośredniej weryfikacji dla osób bez przygotowania teoretycznego, ale za to łatwe do przeniesienia na grunt praktyki szkolnej. E-doświadczenia rozumiane są głównie jako prezentacje (choć nie bezpośrednie, bo z wykorzystaniem mediów) wybranych zjawisk poprzez odtwarzanie ich w warunkach kontrolowanych. Celem takich doświadczeń jest zapoznanie dzieci ze stanem faktycznym w myśl zasady: tak jest/tak to działa, więc przyjrzyj się i zapamiętaj. W scenariuszach nie akcentuje się eksperymentów samodzielnie przeprowadzanych przez dzieci, w których wykorzystywałyby one swoją wiedzę osobistą w celu postawienia hipotez, a następnie ich weryfikacji. Pomysły na e-doświadczenia są ciekawe, ale sposób ich prezentacji blokuje istotne procesy poznawcze dzieci. Wszystko jest wyjaśnione, a dzieci w ogóle nie muszą myśleć, a tylko rejestrować. Na przykład przy realizacji tematu „Glina czy plastelina” ścieżka dźwiękowa e-doświadczenia brzmi następująco: 
Na razie moja glina jest dość twarda i mało plastyczna, jednak gdy zacznę ją ugniatać, to pod wpływem ciepła moich dłoni, zaczyna robić się miękka, elastyczna i daje łatwo się formować. Od czasu do czasu moczę dłonie w misce z wodą, nie dlatego aby je obmyć, ale po to, aby nawilżyć glinę, by stała się jeszcze bardziej elastyczna. (...) Pamiętajcie, aby nie suszyć ich blisko kaloryferów, lub w pełnym słońcu. Zbyt szybki proces suszenia może spowodować, że figurki popękają.

Dzieci nie mają szans na własne badania i samodzielne wyciąganie wniosków, ponieważ filmiki często kończą się frazami typu: Podsumujmy: atrament zniknąt w goracej wodzie, stało się tak dlatego, że w zimnej wodzie..., (...) udowodniliśmy, że z mleka można zrobić masto; zdradzę wam sekret (...) woda zniknęta, bo (...). Doświadczenia mają tylko wzbudzić zainteresowanie i skupiać uwagę dzieci: dziś dowiecie się z którego jajka wykluje się kurczak (...); dziś pokażę wam doświadczenie, w którym kapusta czerwona zmieni swoje kolory w zielona i niebieska (...).

Wiele proponowanych e-doświadczeń w ogóle doświadczeniami nie jest, tylko filmowymi prezentacjami miejsc i zjawisk. Dzieci na przykład mogą dowiedzieć się kto żyje w stajni i jakie prowadzi się tam prace, jak powstają zdjęcia, jak rośnie las. W e-doświadczeniach zawiera się też poglądowe instrukcje wykonania różnych przedmiotów: jak domowym sposobem wykonać stetoskop, jak ugotować budyń czy upiec karpatkę, w jaki sposób możemy zrobić prosty instrument muzyczny. Nie wiadomo też jak twórcy scenariuszy rozumieją sformułowanie ,hipoteza doświadczenia”, bowiem czasami jest ona stawiana w formie pytań, np.: Jak można stwierdzić, że jajko jest zapłodnione czyli wykluje się z niego pisklę?; Co jest większym skarbem Ziemi - sól czy węgiel? Niekiedy te „hipotezy” wskazują na bardzo banalny problem, np.: Czy każdy z nas może zrobić karmnik?

Zaprzepaszczanie okazji do traktowania e-doświadczeń jako intelektualnych wyzwań jest widoczne w poszczególnych zapisach przebiegu planowanych zajęć. To, że doświadczenia lub eksperymenty nie będą wykonywane przez dzieci jest już sugerowane na poziomie stanowienia celów. Na przykład przy realizacji bloku tematycznego „W świecie filmu i teatru”, przy temacie dnia „Tajemnicza wizyta” w proponowanym zapisie celu lekcji jest: potrafi skupić uwagę na e-doświadczeniu, oraz bezpośrednio w scenariuszu, mimo odwołania się do projektu okazji edukacyjnych sugeruje się: Obejrzycie teraz doświadczenie, w którym pokażemy znikajacy atrament (...). A po projekcji w niektórych konspektach proponuje się zdawkowo: Rozmowa na temat treści zawartych w filmie. Zatem e-doświadczenia pełnią tylko rolę ozdobników, motywatorów, mają rozbić monotonię lekcji.

Drugim ważnym wyróżnikiem podejścia behawioralno-konstruktywistycznego na Scholarisie jest cyfrowość tablicowa, czyli promowanie zbiorowych działań przy tablicy multimedialnej, na której wyświetlane są elementy z zasobów tego portalu. Jeden uczeń pracuje przy tablicy, reszta to tylko obserwuje. Oto przykładowa propozycja:

Nauczyciel wyświetla na tablicy ćwiczenie interaktywne „Wielkanocna niespodzianka”. Kolejne dzieci podchodzą i wpisują (ze słuchu) kolejne hasła. Po uzupełnieniu wszystkich haseł uczniowie liczą litery i zgodnie ze wskazówkami wpisują je do pustych miejsc, uzupełniają hasło: Wielkanoc. 
Lansowany jest zatem model pracy zbiorowej, w którym o nowoczesności zadecyduje używanie innej, nie zielonej jak dotychczas tablicy. Nadal będzie pracował przy niej jeden uczeń, a pozostali będą mogli tylko popatrzeć na efekty jego działania. Z pewnością takie podejście jest spójne z realiami szkół, w których ciągle brakuje multimedialnego sprzętu dla uczniów, z drugiej strony jednak jest to legitymizowanie tradycyjnych sposobów nauczania w majestacie nowych technologii. W metodyce pracy na lekcji nie zmienia się nic, a nowoczesność wyraża się wyłącznie poprzez podmianę wykorzystywanego środka dydaktycznego. To stara metodyka ubrana w nowe piórka.

O podejściu funkcjonalno-behawioralnym w scenariuszach zamieszczanych na Scholarisie świadczy też infantylizacja i banalizacja treści. Obok konspektów interesujących, $\mathrm{z}$ dużym potencjałem w zakresie budzenia motywacji dzieci do działania, w zasobach znajdują się też zdumiewająco banalne propozycje, opierające się bardzo często na luźnych skojarzeniach, zniekształcających rzeczywistość i infantylizujących sprawy ważne. Oto, co przykładowo proponuje się dzieciom przy realizacji tematu „W Kosmosie - kosmiczne opowiadania":

- Charakterystyka Kosmity - opis postaci z własnej wyobraźni.

- Wizerunek Kosmity - rysunek w zeszycie przedmiotowym.

- (...) Dyskusja na temat niebezpieczeństwa ze strony „Obcych”; czy istnieją Kosmici? Kogo powiadomić w razie niebezpieczeństwa?

- Przypominamy numer alarmowy 112.

Proponowana dzieciom dyskusja na temat niebezpieczeństwa ze strony kosmitów ma jałowy charakter. Nie wiadomo dlaczego autorzy scenariusza wiążą korzystanie z tak ważnego numeru telefonu z wyimaginowaną sytuacją ich przybycia na nasza planetę. Wytworzenie niebezpiecznych skojarzeń może skutkować nieodpowiedzialnym zachowaniem w przyszłości.

Szczególnym wyznacznikiem obecności podejścia behawioralno-funkcjonalistycznego w edukacji jest brak zaufania do kompetencji dzieci. Ten rys można zidentyfikować w wielu propozycjach zajęć. Autorzy scenariuszy jakby z góry zakładają, że dzieci posiadają małe doświadczenie i ograniczoną wiedzę o świecie. Na przykład, od ucznia w klasie drugiej, którego co prawda, określono jako „wymagającego pomocy” oczekuje się, by odpowiedział na tak proste pytanie, jak: Co będzie ci potrzebne, aby wykopać gline? $\mathrm{W}$ innym miejscu sugeruje się, by dzieci po obejrzeniu doświadczenia, w którym wykorzystano fragment pieluszki niemowlęcej do wchłonięcia wody w kubeczku opowiedziały o tym $w$ domu, a na pewno ta wiedza zaskoczycie rodziców.

O tradycyjnym podejściu do edukacji na portalu Scholaris świadczy także sztywność metodyczna sugerowanych propozycji. Nauczyciele otrzymują gotowe scenariusze do odtworzenia, ze szczegółowym rozpisaniem celów, środków dydaktycznych, przedstawieniem warstwy realizacyjnej, a nawet podaniem głównych wniosków dla nauczyciela i pożądanych odpowiedzi uczniów, niekiedy dramatycznie oczywistych: Co łaczy ze soba wszystkie prezentowane rzeczy? Wyciagnięcie wniosku, że jest to nadmorskie miasto 
Gdańsk. Przy niektórych e-doświadczeniach przedstawiane są też ścieżki dźwiękowe, według których krok po kroku można je odtwarzać. Tam również odnaleźć można zapisy wyjątkowo banalne, uwłaczające intelektowi zarówno nauczycieli, jak i uczniów, na przykład przy „doświadczeniu” z budową karmnika:

\footnotetext{
Wniosek z doświadczenia:

Zrobienie karmnika nie jest tak skomplikowane, jak można by się było spodziewać. Nie wymaga od nas wielu nakładów finansowych, a przynosi wiele pożytku. Każdy z nas powinien pomagać zwierzętom przetrwać zimę (...).
}

\section{Podsumowanie}

Przeprowadzona analiza pozwala na wyciągnięcie zasadniczego wniosku, że korzystanie przez nauczycieli z zasobów edukacyjnych zgromadzonych na portalu Scholaris przybliży szkołę do cyfrowych trendów obecnych w kulturze, ale nie uruchomi procesu zmian w edukacji. Cyfrowość na portalu jawi się jako obrazowo-dźwiękowe uatrakcyjnianie zajęć oraz techniczne ułatwianie pracy nauczyciela. Mimo wyraźnej tendencji nowatorskich przejawiających się w proponowaniu e-doświadczeń, ogólny model lansowanej na portalu edukacji należy uznać za funkcjonalno-behawioralny. Można powiedzieć, że Scholaris proponuje tylko ścieżkę w stronę konstruktywizmu, natomiast wyznacza autostradę w kierunku modelu tradycyjnego, transmisyjnego. Wskazywane wykorzystanie nowych technologii utrwala, wręcz ,cementuje” frontalne nauczanie, tylko przy nowej, bo cyfrowej tablicy. Warto rozważyć rzeczywiste unowocześnienie cyfrowej oferty dla szkół prezentowanej w Scholarisie w następujących kierunkach:

- rozszerzenie otwartości platformy na inne miejsca sieciowe z zasobami, inne społeczności i inicjatywy;

- ograniczenie dostarczania gotowych wzorów działania na rzecz generowania narzędzi cyfrowych do wykorzystania na poziomie wczesnoszkolnych;

- otwarcie na alternatywność w stosunku do podstawy programowej;

- uwzględnianie w propozycjach rzeczywistej aktywności intelektualnej dziecka, zgodnej z zaleceniami edukacji konstruktywistycznej.

Zgodnie z modelem rozwoju technologii w edukacji sugerowana na portalu Scholaris cyfrowość pozostaje na etapie zastosowania, czyli prostego dodawania technologii do istniejącej praktyki (Sysło 2010: 38). Kolejne etapy (integracji i transformacji) jeszcze przed nami. Jednakże istotna jest refleksja, czemu służy nasycanie codzienności szkolnej technologią. Ujawniony tu kierunek cyfryzacji wczesnej edukacji nie oznacza unowocześniania szkoły, a tylko utrwala dawno krytykowany i nieodpowiadający współczesnej dydaktyce model pracy z dziećmi. 


\section{Literatura}

Cichocki P., Jędrkiewicz T., Zydel R. (2012), Etnografia wirtualna. W: D. Jemielniak (red.), Badania jakościowe. Metody i narzędzia. Tom 2, Warszawa, Wydawnictwo Naukowe PWN.

Dumont A. Istance D. (2013), Analiza i tworzenie środowisk uczenia się w XXI wieku. W: H. Dumont, D. Istance, F. Benavides, Istota uczenia się. Wykorzystanie wyników badań w praktyce. Warszawa, Wolters Kluwer.

Klus-Stańska D. (2009), Dyskursy pedagogiki wczesnoszkolnej. W: D. Klus-Stańska, M. Szczepska-Pustkowska (red.), Pedagogika wczesnoszkolna - dyskursy, problemy, rozwiąania. Warszawa, WAiP.

Kruk J. (2009), Przestrzeń i rzeczy jako środowisko uczenia się. W: D. Klus-Stańska, M. Szczepska-Pustkowska (red.), Pedagogika wczesnoszkolna - dyskursy, problemy, rozwiazania. Warszawa, WAiP.

Levinson, P. (2010), Nowe nowe media. Kraków, Wyd. WAM.

Łukaszewicz R.M. (2010), Wrocławska Szkoła Przyszłości. Wrocław, Fundacja Wolne Inicjatywy Edukacyjne.

Mautner G. (2011), Analiza gazet, czasopism i innych mediów drukowanych. W: Wodak R., Krzyżanowski M. (red.), Jakościowa analiza dyskursu w naukach społecznych. Warszawa, Oficyna Wydawnicza „Łośgraf”.

Mendel M. (2006), Pedagogika miejsca i animacja na miejsce wrażliwa. W: M. Mendel (red.), Pedagogika miejsca. Wrocław, Wydawnictwo Naukowe DSW TWP we Wrocławiu.

Nowak J. (2014), Szkoła - nowe przestrzenie edukacyjne. W: M. Magda-Adamowicz, I. Kopaczyńska (red.), Pedagogika wczesnoszkolna wobec zmieniajacych się kontekstów społecznych. Tom 1, Toruń, Wydawnictwo Adam Marszałek.

Peräkylä A. (2009), Analiza rozmów i tekstów. W: N.K. Denzin, Y.S. Lincoln (red.), Metody badań jakościowych. T. 2. Warszawa, Wydawnictwo Naukowe PWN.

Rubacha K. (2008), Metodologia badań nad edukacja. Warszawa, WAiP.

Skura M., Lisicki M., Radanowicz E., Olszańska H., Kulik J. (2014), Innowacyjny program nauczania pn. „Włącz myślenie”, Suchań, br.w.https:/www.suchan.pl/pliki/suchan/pliki/Innowacyjny $\% 20$ Program $\% 20$ Nauczania $\% 20-\% 20 \mathrm{~W} \% \mathrm{C} 5 \% 81 \% \mathrm{C} 4 \% 84 \mathrm{CZ} \% 20 \mathrm{MY} \% \mathrm{C} 5 \% 9 \mathrm{ALE}-$ NIE\%20.pdf

Sysło M. (2010), Co pozostaje w edukacji z przemijającej technologii? „Edukacja i Dialog” nr 09/10. Wadsworth B. (1998), Teoria Piageta. Poznawczy i emocjonalny rozwój dziecka. Warszawa, WSiP. Wieczorek-Tomaszewska M. (red.) (2013), Dydaktyka cyfrowa epoki smartfona. Analiza cyfrowych aspektów dydaktyki gimnazjum i szkoły średniej. Stowarzyszenie „Miasta w Internecie”, www. ldc.edu.pl

Zasada M. (2014), E-Poradnik dla nauczycieli wdrażających Innowacyjny Program Nauczania / IPN/ projektu ,Włacz myślenie - innowacyjny program nauczania i obudowy dydaktycznej dla całego I etapu edukacyjnego" https://www.suchan.pl/pliki/suchan/pliki/E-poradnik\%20dla\%20 nauczycieli\%20w\%20ramach\%20IPN\%20W\%C5\%82\%C4\%85cz\%20My\%C5\%9Blenie.pdf

Zwiernik, J. (2015), Przestrzenie i miejsca w krajobrazie dzieciństwa. W: T. Sadoń-Osowiecka (red.), Miejsce, przestrzeń, krajobraz: edukacyjne znaki. Gdańsk, Wydawnictwo UG. 